\title{
Delação Premiada no Direito Brasileiro
}

Thaylana Almeida Mota ${ }^{1}$; Carmelita Poliana Bertulino Leite ${ }^{2}$

Resumo: Este trabalho advém da análise da Delação Premiada, que é um instituto com diversos entendimentos no ordenamento jurídico brasileiro, exprimindo opiniões favoráveis e contrárias à sua prática. Esta monografia visa abordar de forma concisa e crítica, tal instituto, com utilização de temas chaves, em especial no que tange aos institutos jurídico-sociais que se vinculam ao mesmo e as razões que ensejam sua aplicação, seu valor probatório, bem como garantias e princípios concernentes a essa prática. O presente trabalho, ainda, fornece a conceituação da Delação Premiada, advinda de sua bagagem histórica, bem como estabelece uma compreensão acerca de sua aplicabilidade.

Palavras-chave: Delação Premiada. Valor probatório.

\section{Plea Bargaining in Brazilian Law}

Abstract: This paper comes from analysis of plea bargaining, which is an institute with different understandings in the Brazilian legal system, expressing opinions favor and against the practice. This paper aims to address concisely and critically, such an institute, using key issues, particularly with respect to legal and social institutes that are linked to it and the reasons giving rise their application, their probative value, as well as guarantees and principles concerning this practice. This paper also provides the concept of plea bargaining, arising from its historical background and establishes an understanding of its applicability.

Keywords: Plea Bargaining. Probative value.

\section{Introdução}

Diante da insegurança pública que vem ocorrendo no Brasil, que há tempos vem se deteriorando a níveis inaceitáveis, buscou o legislador uma forma de diminuir insegurança, que gradativamente vem adquirindo novas feições, introduzindo por meio da Lei $\mathrm{n}^{\mathrm{o}}$ 8.072/90 e, posteriormente, em outros diplomas legais, tais como, Leis $\mathrm{n}^{\text {os }}$ 9.034/95, 9.080/95, 9.613/98 e 9.807/99 e 10.409/02, o instituto da delação premiada no ordenamento jurídico pátrio.

A expressão delação não é nada mais do que o "ato de delatar; denunciar; revelar, manifestar, mostrar". Trata se de termo de origem etimológica latina delatio, ónis. Diz ser premiada por dela se originar recompensa àquele que dela se utiliza.

\footnotetext{
${ }^{1}$ Bacharel em Direito - Thaylanamota@hotmail.com

${ }^{2}$ Bacharel em Direito pela Universidade Regional do Cariri - URCA. Pós Graduada em Direito e Processo do Trabalho pela Faculdade Leão Sampaio. Servidora Pública - Analista Judiciária - Tribunal de Justiça do Ceará. Email: cbl.adv@ hotmail.com
} 
A figura da delatio faz-se presente em países como Itália (pattegiamento), Estados Unidos (bargain), Alemanha, Espanha, França e Inglaterra.

Consiste na confissão, pelo acusado, de sua participação no delito a que lhe é imputado, com a atribuição da participação de outro (s) no mesmo fato. É um tema muito polêmico, uma vez que o acusado, ao confessar e incriminar seu (s) comparsa (s) poderá ser beneficiado com a diminuição de pena ou o perdão judicial, desde que preenchidos alguns requisitos, fato este que demonstra a importância de um estudo mais aprofundado acerca do tema.

A pesquisa monográfica discorre sobre principais críticas relacionadas a este instituto, abordando os princípios e o que isso interfere no direito subjetivo do acusado.

Um dos principais pontos do presente trabalho é a descrição do momento da delação, abordando o aspecto da voluntariedade e espontaneidade do acusado, fazendo uma análise nos diplomas legais que preveem esse instituto, buscando identificar se a delação premiada é tida como força incriminatória ou mera prova instrutória.

O objetivo principal do tema é aprofundar o conhecimento sobre delação premiada, abordando a sua natureza, o valor da prova anômala de grande importância para instrução criminal.

Entretanto, essa força condenatória, paira profunda divergência na doutrina e jurisprudência, concernente à violação ou não do princípio do contraditório, da proporcionalidade e de outros princípios constitucionais abordados na presente monografia.

Há quem vislumbre a colaboração ativa, na sua essência, como um ato de traição, indefensável, o que a torna eticamente reprovável.

As críticas surgem também no sentido de que há, com a introdução desse instituto no Direito Pátrio, demonstração da ineficácia do Estado em combater as mais diversas modalidades de ação criminal.

A metodologia utilizada no presente trabalho monográfica caracterizar-se-á como estudo descritivo, analítico, desenvolvido através de pesquisas. Quanto à abordagem, será denominada de caráter qualitativo, tendo em vista que irão ser aprofundados os principais aspectos da delação premiada.

No primeiro capítulo, busca-se fazer uma explanação a respeito do conceito histórico da delação premiada, bem como aborda a sua natureza jurídica, fazendo uma análise deste instituto nos diplomas legais que preveem a delação premiada, destacando seu valor probatório e o momento de aplicabilidade nos casos práticos.

O segundo capítulo irá abordar aspectos fundamentais da delação premiada sob a ótica da Constituição Federal e o papel do Estado na aplicação deste instituto com reflexos na sociedade.

O terceiro capítulo faz uma análise dos requisitos da delação premiada como ato voluntário e/ ou espontâneo, destacando os principais princípios que tangem a este instituto, ressalvando os aspectos polêmicos de ordem prática. 
Por fim, o quarto capítulo é destinado a um estudo de caso, que serviu como base de inspiração para o presente trabalho monográfico tão abordado atualmente devido à força da mídia.

\section{Delação Premiada}

O primeiro capítulo abordará um breve relato histórico da delação premiada, bem como a natureza jurídica e o conceito deste instituto, perfazendo a explicação dos principais pontos para melhor entendimento dos capítulos seguintes.

\section{Breve Histórico}

$\mathrm{O}$ instituto da delação premiada é bastante recente no ordenamento jurídico pátrio e foi disciplinado somente no final do século XX. Porém, desde os primórdios das civilizações, há relatos na história de delatores que receberam recompensa, em razão de sua traição, e que permaneceram marcados na história como eternos traidores.

Um dos exemplos mais marcantes, podemos extrair de um relato bíblico em que Judas Iscariotes que, por determinada quantia, traiu Jesus Cristo, levando o exército romano até o se encontro, permitindo sua captura.

$\mathrm{Na}$ Idade Média são fortes indícios de delação durante o período da Inquisição, no qual se costumava valorar a confissão de acordo com o mecanismo usado para abstrair as informações, assim, se o corréu confessava de forma espontânea, o entendimento era que ele estava inclinado a mentir em prejuízo de outra pessoa, diferentemente daquele que era torturado. Portanto, a confissão mediante tortura era mais valorizada naquela época. (BARREIROS, 1981, p. 31-33.).

Na década de 70, a Itália se destaca nesse instituto na tentativa de combater atos de terrorismo. Porém, recebe maior destaque após uma operação (operazione mani pulite) que tentou exterminar com os criminosos da "máfia". Os delatores ficaram conhecidos como pentiti, e desde então esse conteúdo passou a ser contemplado no Código Penal daquele país. Estabeleceu-se assim uma pena menor para os coautores de crimes como, por exemplo, extorsão mediante sequestro, insubordinação da ordem democrática e sequestro com finalidade terrorista; desde que atendidas às exigências legais. (PACHI, 1992, p. 12).

No sistema Norte Americano, como expõe João Gualberto Garcez Ramos (2006, p.188), a delação premiada existe como uma forma de mostrar resultados práticos e objetivos à sua sociedade. Neste modelo, conhecido como plea bargaining, o representante do Ministério Público norteia a coleta de provas no inquérito policial e faz a acusação diante ao judiciário. Assim, quando surge a 
possibilidade de acordo com o acusado, o Ministério Público tem total autonomia para negociar e decidir pelo prosseguimento ou não da acusação.

$\mathrm{Na}$ Alemanha o modelo kronzeugenregelung (regulação dos testemunhos), ao contrário do modelo plea bargaining americano, o poder é discricionário ao Juiz, e a vantagem pode ser concedida ainda que o resultado não tenha se materializado por circunstâncias alheias a vontade do delator. Existe previsão legal para a diminuição ou poderá chegar até mesmo no perdão da pena para aquele agente que voluntariamente denuncie ou impeça a prática de um crime por organizações criminosas. (GUIDI, 2006, p. 109-110).

$\mathrm{Na}$ Espanha, o benefício em questão é denominado arrependimento e Segundo Bittar (2011, p.08-10), a introdução do instituto no Direito Espanhol teve origem com a Lei Orgânica $n^{\circ} 3$, de 25 de maio de 1988, que previu a redução parcial ou a extinção da pena no caso de houvesse a colaboração de participantes do crime de terrorismo com a justiça, o que se deu tanto devido a uma tendência dos países europeus em se preocupar com essa questão como também em razão dos ataques bascos. Contudo, a previsão de cláusula premial não ficou restrita apenas ao terrorismo, estendendo-se também, com o novo Código Penal (L. O. n 10, de 23 de novembro de 1995), para o delito de tráfico de drogas e relacionados, não se exigindo nesse caso a confissão dos fatos, mas o abandono voluntário das atividades delitivas e a colaboração ativa para impedir o resultado criminoso ou para obter provas que levem aos demais autores ou que impeçam a atividade ilícita.

No Direito Brasileiro, os primeiros registros da delação premiada podem ser verificados nas Ordenações Filipinas que se dar entre os anos de 1603 a 1867, e trazia um livro específico que abordava sobre a delação premiada em crimes de falsificação de moeda.

Ainda neste período de Ordenações Filipinas, é possível destacar um movimento históricopolítico da história do Brasil, que foi a Inconfidência Mineira, em que o Coronel Joaquim Silvério dos Reis obteve o perdão de suas dívidas com a Coroa Portuguesa em troca da delação de seus colegas, que foram presos e acusados do crime de lesa-majestade (traição cometida contra a pessoa do Rei). Dentre os participantes, Joaquim José da Silva Xavier foi tido como chefe do movimento e, consequentemente, condenado à morte por enforcamento. Depois de executado, teve sua cabeça exposta na cidade de Vila Rica, a fim de dissipar outras possíveis revoluções contra o governo. (GUIDI, 2006, p. 110).

Outro período que também merece destaque é o do Regime Militar, a partir de 1964, em que a delação premiada era muito utilizada para descobrir as pessoas que não concordavam com aquele modelo de governo e, portanto, eram consideradas criminosas.

Apesar de todos esses registros, a delação premiada propriamente dita passa a fazer parte do nosso ordenamento jurídico com a Lei dos Crimes Hediondos ( $\mathrm{n}^{\circ}$ 8.072/90), que trouxe como pressuposto o efetivo desmantelamento da quadrilha ou bando que tenha sido formada para fins de praticar crimes considerados hediondos; possibilitando assim uma diminuição de pena. A partir de 
então, a delação premiada foi introduzida em vários diplomas legais e vem ganhando força na mídia devido aos escândalos de corrupção, esquemas de desvio de verbas envolvendo a alta cúpula do governo.

\section{Conceito e natureza jurídica da Delação Premiada}

A expressão "delação" tem origem do latim delatione, significando denunciar, revelar (crime ou delito); acusar como autor de crime ou delito; deixar perceber; denunciar como culpado; denunciarse como culpado; acusar-se. (FERREIRA, 1999, p.617)

O conceito jurídico de delação premiada, na ótica de Adalberto Aranha (1999, p. 217), consiste na afirmativa feita por um indiciado, ao ser interrogado em juízo ou na polícia, na qual além de confessar a autoria de um fato criminoso, atribui, comprovadamente, a um terceiro a participação como seu comparsa.

Neste mesmo sentido, continua Tourinho Filho (2005, p. 239), referindo-se à imputação de corréu na "delação" ou "chamamento de cúmplice", ocorre que no interrogatório do réu, além de reconhecer sua responsabilidade, este incriminará outro, atribuindo-lhe participação.

Luiz Flávio Gomes (2005, p. 18) faz uma observação muito importante e explica que delação premiada e colaboração à justiça não são sinônimos. Assim, o agente, no curso da investigação criminal, poderá assumir a culpa sem incriminar terceiros, caso em que é mero colaborador, sem que se levantarem questionamentos éticos acerca de seu ato.

Em relação à natureza jurídica da delação premiada, tem-se que é mero instrumento probatório em detrimento do livre convencimento do juiz. Porém, prevalece na doutrina que há ausência de semelhança com qualquer tipo de prova nominada.

\section{Requisitos para a sua concessão}

Conforme previsto em legislação brasileira, o réu poderá ter como premiação a extinção da sua punibilidade, tanto na forma de perdão judicial, como na forma de diminuição de pena, desde que atendam aos requisitos. (GRECO, 2009, p 250).

Algumas leis falam em colaboração voluntária e outras falam de colaboração espontânea, ou ainda em réu-colaborador.

Tanto a colaboração voluntária como a espontânea ocorre sem a intervenção humana, ou seja, ambas deverão partir da livre vontade do agente, sem a intervenção de terceiros, e principalmente não poderão ser cumuladas. Sendo assim, se a lei exige espontaneidade o acusado deverá agir como se 
fosse um desejo pessoal deste, já na voluntariedade não importa se o acusado age com espontaneidade, podendo ser a ideia do benefício da delação premiada de um terceiro, mas o acusado deve estar de acordo e não sofrer nenhum tipo de coação.

Já no que tange o réu-delator, este deve denunciar seu bando ou quadrilha e outras apenas os coautores do crime.

Em todas as situações, as informações prestadas pelo réu deverão ser precisas, efetivas e eficazes, contribuindo para o desvendamento das investigações infrações penais, colaborando assim para que o Estado identifique os agentes da organização criminosa. Logo, a concessão do benefício da delação premiada, é, portanto, um direito público e subjetivo do réu, desde que estejam presentes os requisitos da delação premiada.

\section{Uma análise das leis que norteiam a Delação Premiada}

Abaixo analisaremos os principais diplomas legais que preveem a aplicação da Delação Premiada:

\section{Lei de Combate ao Crime Organizado}

O instituto da delação ingressou no Direito Brasileiro através da Lei n. 8.072/90 (Lei dos Crimes Hediondos), que em seu parágrafo único do artigo $8^{\circ}$ menciona: "O participante e o associado que denunciar à autoridade o bando ou quadrilha, possibilitando o seu desmantelamento, terá a pena reduzida de um a dois terços.”

Para receber a redução de pena, o deverá denunciar o grupo criminoso e aguardar o objetivo a ser alcançado pela autoridade, ou seja, conseguir a destruição ou extinção daquela organização criminosa. A lei não estabeleceu especificamente no que consiste o desmantelamento do bando ou quadrilha.

\section{Lei da Organização Criminosa}

Para Cervini e Gomes (1995, p. 50) as organizações criminosas compõem-se de coordenação e divisão de tarefas, instituindo-se numa relação de subordinação e ajuda mútua entre indivíduos envolvidos do grupo criminoso. Existe uma semelhança de interesses, onde há uma divisão de trabalho com interdependência entre seus membros, com o intuito de alcançarem o maior lucro possível na execução dos crimes.

Com a finalidade de combater este tipo de crime como esse, o legislador estabeleceu a delação premiada no artigo $4^{\circ}$ da Lei n. 12.850/13 que diz: 
Art. 4ำ $\mathrm{O}$ juiz poderá, a requerimento das partes, conceder o perdão judicial, reduzir em até $2 / 3$ (dois terços) a pena privativa de liberdade ou substituí-la por restritiva de direitos daquele que tenha colaborado efetiva e voluntariamente com a investigação e com o processo criminal, desde que dessa colaboração advenha um ou mais dos seguintes resultados:

I - a identificação dos demais coautores e partícipes da organização criminosa e das infrações penais por eles praticadas;

II - a revelação da estrutura hierárquica e da divisão de tarefas da organização criminosa;

III - a prevenção de infrações penais decorrentes das atividades da organização criminosa;

IV - a recuperação total ou parcial do produto ou do proveito das infrações penais praticadas pela organização criminosa;

V - a localização de eventual vítima com a sua integridade física preservada

Observa-se que o legislador nesta nova redação é taxativo em relação ao rol de resultados proveniente da delação premiada.

\section{Lei dos Crimes Contra a Ordem Tributária}

Estão expostos na Lei n. 8.137/90 os crimes contra a ordem tributária, econômica e contra as relações de consumo. O instituto da delação premiada foi previsto através da Lei n. 9.080/95, acrescentando o parágrafo único ao artigo 16 da Lei dos Crimes contra Ordem Tributária (Lei ${ }^{\circ}$ 8.137/90), in verbis: "Nos crimes previstos nesta Lei, cometidos em quadrilha ou coautoria, o coautor ou partícipe que através da confissão espontânea revelar à autoridade policial ou judicial toda a trama delituosa terá a sua pena reduzida de 1 (um) a 2/3 (dois terços). “

Como a lei fala em autoridade, a confissão pode dar-se tanto perante polícia, como no membro do Ministério Público, ou diante da até mesmo diante autoridade judiciária. Desta forma o delator que revelar toda a trama delituosa fará jus ao benefício da delação premiada.

\section{Lei dos Crimes Contra o Sistema Financeiro Nacional}

Os crimes contra o Sistema Financeiro Nacional foram tipificados na Lei n. 7.492/86, mais conhecida como Lei do Colarinho Branco, busca reprimir estes crimes que causam enormes prejuízos à sociedade. A delação premiada através da Lei n. 9.080/95 acrescentou o $\$ 2^{\circ}$ ao artigo 25 da Lei do Colarinho Branco, in verbis:

Nos crimes previstos nesta lei, cometidos em quadrilha ou coautoria, o coautor ou partícipe que através da confissão espontânea revelar à autoridade policial ou judicial toda a trama delituosa terá sua pena reduzida de 1 (um) a 2/3 (dois terços).

Assim, exige o texto legal, uma confissão espontânea do agente que revele a trama delituosa e todos os envolvidos. De acordo com consoante Maia (1999, p 150): 
A confissão deverá desnudar todo o iter criminis e apontar os que dele participaram, sendo certo que tais elementos deverão ser objeto de comprovação probatória, para ensejar aplicação do benefício. O crime deve ser oriundo de atuação de quadrilha (art. 288 do CP) ou resultante de concurso de agentes, integrados, em qualquer caso, pelo próprio delator.

A confissão espontânea poderá ocorrer na fase inquisitória ou na fase judicial, perante a autoridade policial e judicial, respectivamente.

\section{Crime de Extorsão Mediante Sequestro}

O artigo $7^{\circ}$ da Lei n. 8.072/90 (Lei dos Crimes Hediondos) que estabelece que a delação premiada ao $\S 4^{\circ}$ do artigo 159 do Código Penal, originalmente nesses termos: "Se o crime for cometido por quadrilha ou bando, o coautor que denunciá-lo à autoridade, facilitando a libertação do sequestrado, terá sua pena reduzida de 1 (um) a 2/3 (dois terços)."

Diante da imperfeição técnica e da crítica geral recebida, a redação do $\S 4^{\circ}$ do artigo 159 da lei substantiva foi corrigida pela Lei n. 9.269/96, in verbis: "Se o crime for cometido em concurso, o concorrente que o denunciar à autoridade, facilitando a libertação do sequestrado, terá a pena reduzida de 1 (um) a 2/3 (dois terços)."

O novo dispositivo é bem mais adequado que o anterior, ao passo que permite a aplicação da delação premiada mesmo que seja só em concurso de agentes, não sendo mais necessária exigência da configuração de quadrilha ou bando.

Assim, o bem jurídico a ser protegidos nestes crimes é a vida, com a delação premiada procura-se evitar possíveis tragédias, como por exemplo, a morte da pessoa sequestrada.

\section{Lei de Lavagem de Capitais}

A delação premiada prevista da Lei n. 9.613/98 deu maior estímulo ao delator, pois o juiz pode evitar que este ingresse nas prisões do sistema penitenciário brasileiro, concedendo-lhe o cumprimento da pena em regime aberto, a substituição por pena restritiva de direito, e até mesmo, isenção de pena, diminuindo as chances de represália. $O \S 5^{\circ}$ do artigo $1^{\circ}$ da Lei de Lavagem de Capitais estabelece:

A pena será reduzida de 1 (um) a 2/3 (dois terços) e começará a ser cumprida em regime aberto, podendo o juiz deixar de aplicá-la ou substituí-la por pena restritiva de direitos, se o autor, coautor ou partícipe colaborar espontaneamente com às autoridades, prestando esclarecimentos que conduzam à apuração das infrações penais e de sua autoria ou à localização dos bens, direitos ou valores objeto do crime (Lei n. 9.613/98, art. $1^{\circ}, \S 5^{\circ}$ ). 
A lei estabeleceu três opções quanto à aplicabilidade da pena ao julgador, este deverá analisar: o nível de colaboração espontânea, a relevância dos esclarecimentos, a participação do delator nos crimes e as consequências gravosas do crime de lavagem.

Desta forma, para que o agente seja beneficiado é necessário que as informações conduzam à pronta solução das infrações e que possibilitem a localização de bens, direitos ou valores objeto da lavagem.

\section{Lei de Proteção às Vítimas e Testemunhas}

A Lei n. 9.807/99 estabeleceu o Programa Federal de Assistência a Vítimas e Testemunhas ameaçadas, dispondo sobre a proteção de acusados ou condenados que tenham voluntariamente prestado efetiva colaboração à investigação policial e ao processo criminal. A delação premiada nesta lei institui que a colaboração do réu para investigação e para o processo pode dar causa a extinção de sua punibilidade, em razão do perdão judicial, ou gerar redução de sua pena.

$\mathrm{O}$ artigo 13 da lei supramencionada aduz que:

Poderá o juiz, de ofício ou a requerimento das partes, conceder o perdão judicial e a consequente extinção da punibilidade do acusado que, sendo primário, tenha colaborado efetiva e voluntariamente com a investigação e o processo criminal, desde que dessa colaboração tenha resultado: I- a identificação dos demais coautores ou partícipes da ação criminosa; II- a localização da vítima com a sua integridade física preservada; III- a recuperação total ou parcial do produto do crime. Parágrafo único: a concessão do perdão judicial levará em conta a personalidade do beneficiado e a natureza, circunstâncias, gravidade e repercussão social do fato criminoso.

A autoridade policial é a competente para conceder o perdão judicial que extinguirá a punição do crime, podendo atuar de oficio ou provocada pelas partes. Cabe ao conceder o perdão judicial quando o delator preencher os requisitos subjetivos e objetivos. Não será concedido o perdão e sim a redução da pena para o delator que colaborar voluntariamente com a investigação e processo criminal, que não preencha todas as exigências do artigo 13 da Lei n. 9.807/99.

\section{Lei Antitóxicos}

A nova Lei Antitóxicos, n. 11.343/2006, prevê a delação premiada para o traficante de drogas colaborador da justiça, em seu artigo 41, in verbis:

O indiciado ou acusado que colaborar voluntariamente com a investigação policial e o processo criminal na identificação dos demais coautores ou partícipes do crime e na recuperação total ou parcial do produto do crime, no caso de condenação, terá a pena reduzida de $1 / 3$ (um terço) a 2/3 (dois terços). 
Dessa forma, para o delator receber o benefício, a sua colaboração deve ter sido voluntária, ou seja, um ato livre e consciente do sujeito, sem qualquer espécie de coação física ou moral. O valor da delação como meio de prova, é difícil de ser apurado com precisão.

Porém, é importante destacar que atualmente existem várias normas dispondo sobre a delação premiada, isto é, sobre a denúncia, que tem como objeto narrar às autoridades o cometimento do delito e, quando existente, os coautores e seus partícipes, com ou sem resultado concreto, conforme o caso, recebendo em troca do Estado, um benefício qualquer, consistente em diminuição de pena ou, até mesmo em perdão judicial.

As informações prestadas deverão estar relacionadas com a ação penal, devendo ter um alto grau de importância, e sendo elas imprecisas ou mentirosas o benefício delação estará completamente comprometido. José Alexandre Marson Guidi (2006, p 167) aduz que: “Assim, para se estabelecer os requisitos primordiais acerca da delação premiada, dever-se-á observar as regras contidas em todas as leis que invocam o instituto e, fazendo uma "ginástica jurídica", tentar aplicar no caso concreto de modo único.".

\section{Delação Premiada como meio de prova}

Quanto ao valor atribuído à delação como prova, existe forte divergência doutrinária e jurisprudencial. Alguns atribuem força incriminadora, enquanto outros a consideram como mera prova indiciária, devendo ser respaldada nas demais provas dos.

Para Fernando Capez (2003, p. 289), a delação possui o valor de prova testemunhal na parte referente à imputação e admite reperguntas por parte do delatado. Em sentido contrário, Aranha (1999, p 125-126) aduz que: "A chamada do corréu, como elemento único de prova acusatória, jamais poderia servir de base a uma condenação, simplesmente porque violaria o princípio constitucional do contraditório.".

Percebe-se que este entendimento foi expresso antes da vigência da Lei 10.792/2003, que alterou o Código de Processo Penal, concedendo natureza contraditória ao interrogatório, e, consequentemente, maior valor como prova. É neste sentido a opinião de Damásio de Jesus (online): "A delação (não-premiada) de um concorrente do crime por outro, em sede policial ou em juízo, denominada "chamada de corréu" ou "confissão delatória", embora não tenha o condão de embasar, por si só, uma condenação."

Não se pode deixar de considerar que existe um grande apelo em relação ao prêmio punitivo, podendo gerar suspeitas quanto à verdade das informações prestadas pelo delator. É uma ressalva Malatesta (1995, p. 208-209), conforme transcrição abaixo: 
Sempre que, repetimos, a acusação em sentido genérico do cúmplice se apresente como desagravo do acusado acusador, a suspeita na veracidade deste é legítima. Disto deriva que esta suspeita se tornará imensa quando prometida a impunidade pela revelação dos cúmplices. O impulso para mentir é tão forte que a lógica se opõe a fazer menção de tal chamada de cúmplice, cujo preço é a impunidade do delator.

Apesar da reserva feita pelo doutrinador, entende-se ser esta relevável, dado que o alcance de um resultado é requisito essencial da grande maioria das hipóteses de delação premiada contemporânea.

\title{
Momento da Delação
}

Na Lei do Crime Organizado não há previsão temporal para a delação premiada, o que já não ocorre com a Lei de Drogas e na Lei de Proteção as Vítimas e Testemunhas, onde se verifica que o momento da delação deverá ocorrer na fase investigatória ou no curso do processo criminal, desta forma, encerrado o processo o acusado não poderá mais se valer deste benefício.

Em regra geral, o momento da delação poderá ocorrer em qualquer fase da investigação ou durante o processo, porém outros doutrinadores entendem que a aplicação da delação poderá ser feita a qualquer momento.

Com pôde-se ver acima, os diplomas legais não tratam do momento em que deve ser apresentada a delação premiada, assim, muito embora a condução do processo facilite para que a delação premiada ocorra no momento do interrogatório do acusado, haja vista que ela deve ser acompanhada de uma confissão, estende-se que esta pode se operar a qualquer momento do processo penal, e até mesmo após o trânsito em julgado da sentença. Neste sentido, merece destaque o ensinamento de Jesus (2005, online, grifo do autor):

\begin{abstract}
A análise dos dispositivos referentes à "delação premiada" indica, em uma primeira análise, que o benefício somente poderia ser aplicado até a fase da sentença. Não se pode excluir, todavia, a possibilidade de concessão do prêmio após o trânsito em julgado, mediante revisão criminal. Uma das hipóteses de rescisão de coisa julgada no crime é a descoberta de nova prova de "inocência do condenado ou de circunstância que determine ou autorize diminuição especial de pena" (art. 621, III, do CPP). Parece-nos sustentável, portanto, que uma colaboração posterior ao trânsito em julgado seja beneficiada com os prêmios relativos à "delação premiada".
\end{abstract}

O argumento de que não seria cabível em fase de execução, por ser o momento de concessão dos benefícios (redução de pena, regime penitenciário brando, substituição de prisão por pena alternativa ou extinção da punibilidade) o da sentença contradiz o art. 621 do CPP que autoriza explicitamente desde a redução da pena até a absolvição do réu em sede de revisão criminal, de modo que este também deve ser considerado um dos momentos adequados para exame de benefícios aos 
autores de crimes, inclusive em relação ao instituto ora analisado. Exigir-se-á, evidentemente, o preenchimento de todos os requisitos legais, inclusive o de que o ato se refira à delação dos coautores ou partícipes do(s) crime(s) objeto da sentença rescindenda. Será preciso, ademais, que esses concorrentes não tenham sido absolvidos definitivamente no processo originário, uma vez que, nessa hipótese, formada a coisa julgada material, a colaboração, ainda que sincera, jamais seria eficaz, diante da impossibilidade de revisão criminal pro societate.

\section{Perdão judicial e causa de diminuição de pena}

Com o advento das Leis 9.613/98 e 9.807/99, foi possibilitado ao juiz aplicar a delação como causa de extinção de punibilidade do agente, reconhecendo que o acusado merece a concessão do perdão judicial.

O perdão judicial é norma pela qual o magistrado, em que pese a prática de delito pelo acusado, deixa de aplicar a pena devido a presença de justificadas peculiaridades. É, para Nucci (2002, p. 25): A legítima "clemência do Estado para determinadas situações expressamente previstas em lei, [...], ao serem preenchidos certos requisitos objetivos e subjetivos que envolvem a infração penal".

Para Mendroni (2002, p 59), estas hipóteses implicam, aparentemente, em uma espécie diferenciada de "perdão judicial", porque, segundo o conceito original desta forma de extinção da punibilidade, ela procura: "[...] deixar de punir aquele que tenha sofrido consequência pessoal tão grave decorrente da sua própria conduta, que se pode considerar por aplicada e cumprida sua pena".

No caso da delação premiada, o agente não sofre nenhuma consequência pessoal. O perdão, neste caso, decorre apenas da colaboração com a justiça.

Por fim, o perdão judicial concedido, sendo causa de extinção da punibilidade, constitui instrumento de despenalização, descabendo, destarte, a inclusão do nome do réu no rol dos culpados e sua condenação em custas, conforme já pacificado na jurisprudência.

Presente a possibilidade de redução de pena do réu em todas as previsões legislativas da delação premiada, resta firmar a posição jurídica que o instituto apresente nesta situação: se é atenuante, circunstância judicial ou causa de diminuição de pena.

Exclui-se, de plano, a figura da atenuante, levando em consideração que a delação premiada não se encontra expressa nos artigos 65 e 66 do Código Penal e que as atenuantes não apresentam o valor exato do quantum a ser reduzido da pena, diferentemente das hipóteses de delação, que têm os limites da referida redução variando entre um sexto a dois terços. Também se pode eliminar a hipótese da delação como circunstância judicial, já que esta não está descrita no artigo 59 do referido código, que alude sobre a dosimetria da pena. 


\section{Aspectos Fundamentais da Delação Premiada no Ordenamento Jurídico Brasileiro}

Este tópico irá abordar aspectos fundamentais da delação premiada em nosso ordenamento jurídico, na ótica de jurisconsultos renomados.

\section{Delação Premiada através da Constituição Federal de 1988}

Desde a introdução da delação premiada no sistema jurídico brasileiro, são corriqueiros os debates em torno deste assunto entre os juristas. Para muitos, além de ser antiético, ele não encontra respaldo na dogmática do sistema jurídico penal brasileiro.

Para outros, como no caso de Moreira (2003, p. 25), ele é desnecessário, porque já existe no sistema brasileiro a figura da atenuante genérica do artigo 65, III, b, além do arrependimento eficaz em seu artigo 15 e do arrependimento posterior, artigo 16, todos previstos no Código Penal.

Contudo, outra corrente de doutrinadores entende que o referido instituto está de acordo com o ordenamento jurídico e atende aos preceitos fundamentados na constituição, (MONTE, 2001, p. 234248).

Assim, pode-se afirmar que todos os dispositivos que previram o prêmio à delação são instrumentos direcionados a promover a segurança e a justiça (direitos que, conforme o preâmbulo da Constituição Federal de 1988 deve ser assegurado pelo Estado Democrático), pois permitem à perseguição penal um recurso sólido para combater à criminalidade organizada e a impunidade no Brasil.

Nesse passo, observam-se as críticas análogas ao pensamento de Pereira (online), que julga insuficiente conceder tamanho poder à discricionariedade do magistrado para apreciar a presença ou não dos requisitos para concessão da delação premiada quando menciona que: "Como se sabe, deixar à apreciação de uma única pessoa um critério que poderá deixar impune criminoso tão perigoso à já indefesa sociedade é critério dos mais temerários."

Utilizando-se as palavras de Monte (2001, p. 247), tal posicionamento deixa clara a crença dominante de que o juiz é mero aplicador da lei que deve ser clara, objetiva e possuir um único sentido, aquele sentido dominante no meio jurídico e que, na quase totalidade das vezes, reproduz o sistema político e econômico que interessa à classe dominante no país.

Assim, existindo cidadãos com direitos fundamentais exigíveis do Estado, caberá ao Poder Judiciário aplicar as normas da Constituição quando provocado, avaliando as normas infraconstitucionais "agora não mais 'livremente', no sentido do descompromisso ideológico, mas 'de acordo com a Constituição". 


\section{Aspectos da Política Criminal no Estado Democrático de Direito Concernentes à Delação Premiada}

A delação premiada é mecanismo de política criminal para opor-se à criminalidade crescente e organizada e diminuir a impunidade, já que, para Maierovitch (1992, p. 301): a política criminal direciona-se à prevenção e repressão dos ilícitos.

Seguindo esse ponto de vista, e levando em consideração que as regras de política criminal devem evoluir juntamente da sociedade, fica claro que o Brasil há muito necessitava de mecanismos que aperfeiçoassem a persecução penal. E a delação premiada, sem romper com nenhum dogma de direito penal e sem descaracterizar a natureza retributiva da pena, resumisse em um desses procedimentos que buscam encurtar a solução dos processos (MONTE, 2001, p. 235).

Tendo a pena finalidade retributiva, preventiva e ressocializadora, entendem que o instituto objeto deste trabalho preenche todas estas finalidades, pois o delator, por ter contribuído com as investigações, acaba por demonstrar um menor grau de reprovabilidade, devendo, em decorrência, receber uma menor censurabilidade - individualizando assim sua pena - e a delação premiada, ao estimular a contribuição com a justiça, serve para ressocializar o agente e inibir futuras ações criminosas e estimular os beneficiados a manterem-se integrados à sociedade - estando de acordo, portanto, com a finalidade da pena.

Não se pode deixar de destacar a necessidade de se oferecer um prêmio ao delator, dado o nítido risco que uma traição traz aos criminosos, normalmente vingativos (AKAOW, 1994, p.430432).

Finalmente, é válido ressalvar que poderão surgir declarações falsas produzidas pelos pretensos colaboradores. Não haverá o que temer nestes casos, pois o juiz: verificará a procedência das informações, como sempre fez na apreciação de todos os meios de prova, desde a confissão até a chamada do corréu.

Reside aqui talvez a discussão mais polêmica sobre este assunto. Como se fez menção anteriormente, diversos juristas debate se a conduta de delatar com o intuito de receber um prêmio estaria de acordo com a ética vigente. Moreira (2003, p. 25-29) faz dura crítica contra a utilização do instituto, pois este estimula a amoralidade, podendo levar a ordem jurídica à corrupção e à promiscuidade.

Franco (2000, p. 253.) segue na mesma direção, citando García-Pablos de Molina e Francisco Bueno Arus, e declarando que falta à delação premiada um fundamento "minimamente ético", pois lastreada unicamente em razão de sua utilidade, sem levar em consideração os custos que possa apresentar a todo sistema legal, construído com base na dignidade da pessoa humana.

Gomes (1997, p. 102), por sua vez, defende ser um equívoco pedagógico enorme colocar na legislação dispositivos que concedem prêmios à um traidor, porque assim estaremos difundindo uma cultura de um Direito como instrumento de antivalores, onde o fim acaba justificando os meios. 
Por outro lado, posiciona-se em sentido oposto outra parte da doutrina. Azevedo (1999, p. 6), por exemplo, pondera que: "O agente que se dispõe a colaborar com as investigações assume uma diferenciada postura ética de marcado respeito aos valores sociais imperantes, pondo-se debaixo da constelação axiológica que ilumina o ordenamento jurídico e o meio social.”.

Para Monte (2001, p. 236), o certo é que: "Com a delação o criminoso rompe com os elos da cumplicidade e com os vínculos do solidarismo espúrio, sendo a sua conduta menos reprovável socialmente, por isso merecedor do benefício do perdão judicial ou da redução de sua pena.".

Silva defende que, acerca da moralidade do instituto, este apresenta dupla vantagem: "Permite ao Estado quebrar licitamente a lei do silêncio que envolve as organizações criminosas, assim como colaborar para o espontâneo arrependimento de investigado ou acusado.”.

E pode-se dizer que esta última opinião está em perfeita harmonia com a mens legis, conforme podemos extrair do item 54 da Exposição de Motivos da Lei 9.613/98.

Nesse passo, não se pode deixar de citar Alves (2003, p. 446-464), que presta sua conclusão sobre o assunto, alegando que, passadas as críticas feitas ao instituto:

Resta à realidade demarcada por um conjunto de normas 'vigentes' que objetivam emprestar maior vigor ao processo penal, ante a açodada desordem que acomete a sociedade, desacreditada que está das soluções judiciárias até então ocorridas sob forte inflação legislativa.

Deduz-se que, não obstante os posicionamentos contrários restam assentas que a delação premiada contém em sua essência elevada propósito, pois se trata de oportunidade concedida ao delinquente de assumir sua culpa e contribuir com a justiça no combate à funesta criminalidade.

Contudo, reforça-se que deverá haver um controle judicial rígido para aplicação deste instituto, a fim de evitar qualquer constrangimento em relação à vontade do colaborador.

Por outro lado, imprescindível uma forte precaução no recebimento da delação, principalmente porque o legislador brasileiro não criminalizou a falsa colaboração como fez o italiano.

Dessa maneira, a delação premiada é instrumento de inegável importância na investigação da criminalidade, considerando os moldes que esta tem apresentado hodiernamente. Havendo o devido controle judicial e cuidando-se para que não ocorram abusos por parte de agentes do Estado em sua aplicação prática, ela deverá, sempre que possível, ser utilizada.

\section{Aspectos Polêmicos e Questionamentos de Oredem Prática}

Após a análise de conteúdo da Delação premiada, neste tópico será abordado os principais aspectos de ordem prática e pontos polêmicos. 


\section{Direito subjetivo do acusado}

Existe uma grande divergência nas doutrinas e jurisprudências em ser o prêmio direito subjetivo público do delator que preencher todos os requisitos legais objetivos e subjetivos. Assim, com relação às hipóteses de perdão judicial, Jesus (2006, p.6) e Leal (2000, p. 450.). Leal afirma, que:

Não obstante a lei utilizar-se da forma verbal poderá, no sentido semântico de mera faculdade, consolidou-se na doutrina e na jurisprudência o entendimento jurídico de se tratar de um poder-dever, que obriga o Magistrado a conceder o benefício sempre que as condições objetivas e subjetivas previstas no direito positivo estiverem presentes no caso concreto sob exame judicial.

Em direção contrária, seguem os pensamentos de Azevedo (1999, p. 6)

[...] preenchidos os requisitos de ordem objetiva, postos expressamente em lei, há dados de natureza subjetiva a serem apreciados judicialmente, consoante o prudente arbítrio do Magistrado. Destarte, não reconhece singelamente o Magistrado, ao conceder o perdão o 'direito ao perdão', mas bem antes o que a decisão jurisdicional ajuíza é o merecimento do perdão judicial em face, inclusive, do atendimento dos requisitos legais.

Em relação às hipóteses de mera redução especial de pena, doutrina e jurisprudência são pacíficas ao definirem-nas como direito subjetivas do delator:

CRIMINAL. HC. EXTORSÃO MEDIANTE SEQÜESTRO. [...] DELAÇÃO PREMIADA. INFORMAÇÕES EFICAZES. INCIDÊNCIA OBRIGATÓRIA. ORDEM PARCIALMENTE CONCEDIDA. [...] A "delação premiada" prevista no art. $159, \S 4^{\circ}$, do Código Penal é de incidência obrigatória quando os autos demonstram que as informações prestadas pelo agente foram eficazes, possibilitando ou facilitando a libertação da vítima. [...] (HC 35.198/SP, Rel. Ministro GILSON DIPP, QUINTA TURMA, julgado em 28.09.2004, DJ03.11.2004 p. 215).

Interpretação contrária não poderia ser feita, dada a utilização uniforme na legislação das expressões "a pena será reduzida" ou "terá a pena reduzida", deixando nítido, dessa maneira, a obrigatoriedade da redução da pena quando preenchidos seus requisitos pelo delator.

\section{Espontaneidade e Voluntariedade}

È importante salientar que há notória diferença realizada pelo legislador brasileiro entre ato voluntário e ato espontâneo. Na doutrina, Leal (p. 443/458, 2000) faz um conceito de forma bem abrangente do termo voluntariedade e Gomes (1997, p. 168), por outro lado, apresenta sua distinção desses preceitos. Em resumo, ato espontâneo é o que surge unicamente da vontade do delator, sem 
qualquer interferência alheia, sendo que este, por si só, considera apropriado tomar certa conduta. Ato voluntário é aquele produzido sem qualquer espécie de coação, independendo se a ideia inicial partiu ou não do agente.

Logo, para obter o benefício decorrente da delação premiada, é necessário que esta tenha origem em ato voluntário ou espontâneo? A resposta irá variar de acordo com a legislação adotada.

As leis 9.034/95, 7.492/86, 8.137/90, 9.613/98 e 10.409/02 exigem, expressamente, a espontaneidade, enquanto a Lei 9.807/99 satisfaz-se com a voluntariedade do ato. Dessa forma, fica ressalvada a aplicação subsidiária da Lei 9.807/99 - dada seu caráter genérico - nos casos previstos nos demais diplomas.

\section{Princípios e garantias fundamentais}

Neste tópico serão abordados princípios e garantias fundamentais concernentes ao tema em análise.

\section{Do direito de não produzir provas contra si mesmo}

Consagrado pela Constituição Federal e um dos mais clássicos princípios, o direito de não produzir prova contra si mesmo, ou princípio da nemo tenetur detegere, é considerado como um princípio fundamental do indivíduo que esteja na sendo processualmente incriminado ou meramente investigado.

No que se refere ao instituto da delação, nas esclarecidas palavras de Maria Elizabeth Queijo (2003, p.55), para que os requisitos da delação possam ser válidos e servirem como prova, é indispensável que o delator tenha ciência do acordo jurídico que estará estabelecendo, das suas repercussões e alcances, bem como tenha sido efetuado em condições de plena liberdade psíquica, não podendo haver coação, fraude ou violência, ou linguagem que leve ao erro o imputado. Também deverá a autoridade e um advogado, que esteja na investigação e seja de sua confiança, esclarecer sobre a não obrigação de colaborar. Porém querendo ele colaborar, deverá expressar sua livre vontade e consentimento.

\section{Da individualização da pena}

O princípio da individualização da pena está gravado no inciso XLVI do artigo $5^{\circ}$ da

Constituição Federal. Para a realização dessa individualização, imprescindível a atividade do legislador e do juiz, cujas tarefas compreendem, segundo Boschi (2000, p130): "Definir o crime, indicar as espécies de penas e apontar os limites", para o primeiro e a de "eleger a pena dentre as possíveis, mensurá-la dentro dos limites e, por último, presidir o processo executório da pena que vier a ser concretizada.". 
Parece evidente que as hipóteses de delação premiada proporcionam ao juiz os critérios que deverão ser analisados para a concessão do prêmio e estes se embasam, principalmente, na apreciação do grau de reprovabilidade do agente. Logo, quanto maior o mérito e mais vigoroso os efeitos da colaboração do agente, menor será a censurabilidade de sua conduta criminosa.

Da mesma forma, é possível que a personalidade do criminoso que contribuiu para a investigação se mostre mais apta a aceitar o apelo dos valores do ordenamento jurídico e que predominam no meio social. Sendo assim, se uma das finalidades da pena é a ressocialização do agente, a delação premiada provê estímulo para que este passe a incorporar uma postura em maior conformidade com o meio social, motivo esse, pelo qual uma reprimenda mais amena torna-se indispensável (MONTE, 2001, p 238).

O que acontece é que a finalidade retributiva da pena está profundamente entalhada na sociedade, fazendo com que haja uma compreensível resistência a permitir que o benefício do perdão judicial seja concedido por meio da delação premiada, bem distante das outras clássicas hipóteses que permitem o perdão, quando as consequências da infração atingem o próprio agente de forma tão grave, que a sanção penal acaba por se tornar desnecessária.

Para o autor Rogério Grecco (2009, p. 71), será de responsabilidade do judiciário a aplicação da pena conforme o crime cometido, e que interpretando o texto constitucional, conclui-se que q primeira fase da individualização da pena ocorre com a seleção feita pelo legislador, quando escolhe para fazer parte do pequeno âmbito de abrangência do Direito Penal, aquelas condutas positivas ou negativas, que atacam bens coletivos mais importantes. Porém, uma vez feita à seleção, o legislador analisa as condutas, inferindo-lhes penas que podem variar de acordo com a importância do bem a ser tutelado.

Assim, é aceitável que duas pessoas que cometeram o mesmo crime serem condenadas a penas diferentes. Portanto, pelo instituto da delação premiada, isto é cabível, tendo em vista a diminuição da pena pelas informações prestadas pelo réu colaborador ou até o perdão judicial, com a completa extinção da punibilidade.

Observa-se então, que a delação premiada não está em desacordo com o princípio da indivisibilidade da ação penal, conforme inscrita no art. 48 do Código de Processo Penal, que nos remete a ação penal privada. A adoção do princípio da divisibilidade para a ação penal pública é a posição amplamente majoritária na jurisprudência, permitindo-se ao Ministério Público excluir algum dos coautores ou partícipes da denúncia, desde que mediante prévia justificação.

\section{Do contraditório e da ampla defesa}

Conforme prevê o artigo $5^{\circ}$ LV da Constituição Federal de 1988, o princípio do contraditório é a garantias de todas as partes envolvidas no processo terem direito de manifestarem, devendo haver 
um equilíbrio na relação estabelecida entre a pretensão punitiva do Estado e o direito à liberdade e a manutenção do estado de inocência do acusado.

Já a ampla defesa, nas palavras de Nucci (2007, p.86): "é um direito concedido ao réu de se valer de amplos e externos métodos para se defender da imputação feita pela acusação, gerando inúmeros direitos exclusivos ao réu, como o caso da revisão criminal.”.

\section{Princípio da proporcionalidade}

O Princípio da Proporcionalidade é, indubitavelmente, o mais importante mecanismo de proteção eficaz da liberdade na ordem constitucional de nossos dias e conforme Feitoza (2009, p. 133):

Urge fazê-lo alvo, pois, das reflexões mais atualizadas em matéria de defesa de direitos fundamentais perante o poder do Estado [. . .] Chegamos, por conseguinte, ao advento de um novo Estado de Direito, à plenitude da constitucionalidade material. Sem o princípio da proporcionalidade, aquela constitucionalidade ficaria privada do instrumento mais poderoso de garantia dos direitos fundamentais contra possíveis e eventuais excessos perpetrados com o preenchimento do espaço aberto pela Constituição ao legislador para atuar formulativamente no domínio das reservas da lei.

Estabelece o entendimento de que alcançada ao patamar de norma-estruturante, a proporcionalidade permite verificar os casos em que há violação às normas (regras ou princípios jurídicos) cuja aplicabilidade ela, define. Sob esse ângulo, um diagnóstico de desproporcionalidade revelará a violação da norma - princípio ou regra - que deixou de ser devidamente observada, e não da proporcionalidade em si. Nessa perspectiva, afetado será o direito de liberdade ao receber uma intervenção inadequada, desnecessária ou desproporcional.

Ou seja, a observância do Princípio da Proporcionalidade é uma forma de impor limites constitucionais que sejam razoáveis e respeitem os direitos fundamentais. A tendência no Brasil e fora dele, é a afirmação da natureza constitucional do princípio da proporcionalidade, possibilitando ao juiz, no sistema brasileiro de controle difuso de constitucionalidade que deixe de aplicar determinada norma legal, por violar o princípio da proporcionalidade e, por conseguinte a Constituição.

Conforme este entendimento, o Estado deve respeitar certos limites constitucionais, aplicando o Princípio da Proporcionalidade nos casos em que a delação premiada se configurar, tanto para o partícipe quanto para o corréu. A proporcionalidade da pena não é um acordo, mas um instituto de natureza pública que não pode se subordinar a um acordo. Dessa forma, se devidamente aplicado o referido princípio, nem a sociedade fica a mercê de injustiças sociais e nem os acusados ficam sem seus direitos e garantias processuais.

No que tange ao instituto delação premiada, verifica-se que há uma afronta aos mencionados princípios, uma vez que a defesa é garantia constitucional, que para sua realização necessita-se de todas as provas existentes nos autos. No entanto, os testemunhos prestados pelos réus-colaboradores 
podem ser mantidos em sigilo, ou seja, com clausula de confidencialidade, o que dificultará, portanto $\mathrm{o}$ acesso às informações para que o acusado possa realizar sua defesa.

\title{
Limites Temporais e Autoridade Competente
}

Não há nos dispositivos legais que preveem a delação premiada qualquer determinação quanto ao momento processual adequado para sua utilização. Destarte, a interpretação mais aceita é a substanciada nas palavras de Gomes (1997, p. 168), que acredita na possibilidade da delação mesmo após o trânsito em julgado da sentença condenatória. Importante frisar-se que existem opiniões diversas sobre qual o meio processual adequado para requerer a delação premiada durante a execução. Damásio de Jesus (2006, p.26-27) opina pela revisão criminal, porém a concepção usual é a de que a delação premiada cuida-se de norma penal mais favorável e, portanto, de aplicação retroativa, atingindo, desse modo, inclusive os crimes cometidos antes da vigência das normas que a preveem. Entendimento esse já confirmado pelo Superior Tribunal de Justiça:

\begin{abstract}
HABEAS CORPUS. PENAL. EXTORSÃO MEDIANTE SEQÜESTRO. VÍTIMA LIBERTADA POR CO-RÉU ANTES DO RECEBIMENTO DO RESGATE. RETROATIVIDADE DA LEI PENAL MAIS BENÉFICA DELAÇÃO PREMIADA. REDUÇÃO DA PENA. ORDEM CONCEDIDA. 1. A libertação da vítima de seqüestro por co-réu, antes do recebimento do resgate, é causa de diminuição de pena, conforme previsto no art. $159, \S 4^{\circ}$, do Código Penal, com a redação dada pela Lei $n^{\circ}$ 9.269/96, que trata da delação premiada. 2. Mesmo que o delito tenha sido praticado antes da edição da Lei ${ }^{\circ}$ 9.269/96, aplica-se o referido dispositivo legal, por se tratar de norma de direito penal mais benéfica [...] (HC 40.633/SP, Rel. Ministro ARNALDO ESTEVES LIMA, QUINTA TURMA, julgado em 01.09.2005, DJ 26.09.2005 p. 417).
\end{abstract}

Por outro lado, também não existem maiores questionamentos acerca de qual a autoridade competente para receber a delação premiada. Esta deverá ser endereçada ao juiz de direito, ao promotor público ou ao delegado de polícia, dependendo, obviamente, do momento processual em que foi prestada.

\section{Delação Premiada e suas extensões aos concorrentes do ato ilícito.}

A respeito desse tópico, dois principais pontos exigem esclarecimento: primeiro, a admissibilidade ou não de sua extensão aos concorrentes do ilícito cometido pelo delator; segundo, a possibilidade do colaborador ser beneficiado pelas informações eficazes que prestar sobre crimes praticados por outros agentes, dos quais não participou e que não se relacionam com o ilícito por ele executado. 
Quanto ao primeiro ponto, opina Pereira (1999, online) e, no mesmo sentido, a jurisprudência dos tribunais superiores que é incomunicável o benefício da delação premiada, por tratar-se de circunstância pessoal, sendo incomunicável e inadmissível sua extensão automática aos corréus.

Já a respeito do alcance desse instituto à fatos que não se relacionam com o ilícito pratico pelo delator, Damásio de Jesus (online) não vê possibilidade de incidência do benefício da delação nestes casos, "uma vez que as normas relativas à matéria exigem que o sujeito ativo da delação seja participante do delito questionado (coautor ou partícipe)".

Mendroni (2002, p.59) discorda parcialmente desse posicionamento. Para ele, a delação pode beneficiar os acusados que prestaram informações sobre delitos concernentes à outros processos em apenas uma única hipótese: quando se tratar da delação premiada prevista na Lei 9.034/95103, "pois, além de se tratar de Lei de cunho genérico, a literalidade de sua expressão parece indicar: '... quando a colaboração espontânea do agente levar ao esclarecimento de infrações penais e sua autoria".

Desse modo, ressalvada a opinião de Mendroni (2002, p.83), de regra o agente não poderá se beneficiar da delação premiada quando esta referir-se a delitos não praticados por ele, mesmo ela sendo eficaz, por ausência de expressa previsão legal.

\section{Os pontos negativos da Delação Premiada}

A opinião quanto a este instituto é bem diversificada, muitos entendem que fornecer vantagens para o delator do crime é um mecanismo de incentivo a traição, contrariando princípios valores mínimos da dignidade humana. Algumas questões podem ser levantadas como, por exemplo, a forma antiética de comportamento social, bem como já abordado anteriormente, poderá ferir a proporcionalidade da aplicação da pena, pois o delator, a depender do acordo, receberia pena menor do que os demais delatados, enquanto estes podem até ter menor participação e mesmo assim, devido a delação, serem penalizados de forma mais grave que o delator.

Outro aspecto bastante questionável e bem interessante, é que muitos que traição serve em regra para agravar ou qualificar a prática de crimes, motivo pelo qual não deveria ser útil para reduzir a pena e que além ser uma forma do estado não pode barganhar com a criminalidade; há um estímulo a delações falsas e um incremento a vinganças pessoais (CUNHA; TAQUES; GOMES, 2009, p. 17).

A delação premiada torna-se reprovável, pois a traição traz prêmios ao delator, sendo que no direito penal em regra, a traição serve para agravar ou qualificar a prática de crimes, razão pela qual a delação não poderia ser usada para reduzir penas.

A Delação Premiada, embora instituto de inegável relevância para a captura, julgamento e eventual condenação de criminosos, é alvo de diversas críticas, com posicionamentos favoráveis - à medida que constitui uma forma de se exercer um controle da criminalidade - e contrárias, tanto da doutrina quanto da sociedade, o que inclui magistrados e membros do Ministério Público, em especial 
no que tange à moralidade e à ética envolvida, uma vez que o fomenta a traição, o que é trazido por Jesus (2006, p. 3), ao afirmar que: "A polêmica em torno da "delação premiada”, em razão do absurdo ético, nunca deixará de existir. Se, de um lado, representa importante mecanismo de combate à criminalidade organizada, de outro, traduz-se como um incentivo legal à traição."

Esses benefícios aos agentes da grande criminalidade são embasados em um direito tecnicista, pragmático, preocupado com a eficiência da atividade legal e jurisdicional, sendo totalmente direcionado ao fim e ao resultado alcançado, que pouco se importa com a ética na qual a justiça deve estar solidificada. Isso é facilmente percebido porque, mesmo diante das críticas doutrinárias ao fato de o Estado beneficiar o traidor dando crédito à imoralidade (instigando a traição) e demonstrar certa fragilidade frente à repressão do crime organizado, podendo até mesmo parecer que quer "comprar" a traição do indiciado, cada vez mais, em busca da efetividade, o Estado premia a colaboração do criminoso "arrependido" (PACHECO; THUMS, 2007, p. 211).

Por fim, a sociedade convive com muitos direitos e garantias constitucionais e os criminosos por sua vez também são beneficiados com tais previsões. Assim, questiona-se que se talvez houvesse uma legislação mais segurança nas sentenças, onde criminosos não sejam beneficiados por simplesmente delatar comparsas e sim recebam sentenças justas de caráter ressocializador, em busca de uma nova sociedade, ou seja, uma sociedade mais segura.

\section{Estudo de Caso}

O presente caso é referente a um processo que tramita na $2^{\mathrm{a}}$ Vara da Comarca de Aquiraz.

O Ministério Público Estadual, por meio da Procuradoria de Justiça dos Crimes Contra a Administração Pública (Procap), ofertou denúncia em desfavor de 5 (cinco) réus com a alegações de crimes de falsificação de documento, corrupção ativa, organização criminosa e peculato, envolvendo funcionários públicos da Prefeitura Municipal de Aquiraz, funcionários públicos do Tribunal de Justiça do Ceará lotados no Fórum de Aquiraz/CE e alguns advogados.

A acusação gira em torno da expedição de alvarás decorrente de processos de desapropriação tramitantes na $1^{\mathrm{a}}$ e $2^{\mathrm{a}}$ Vara da Comarca de Aquiraz/CE, onde o Ministério Público em sua denúncia (autos n48137-78.2014.8.06.0034) alega que a documentação existente nos processos são falsas e investiga também outras condutas criminosas.

Um advogado atuante em um dos processos de desapropriação e também um dos investigados promoveu a delação premiada, colaborando para entrave das investigações e como prêmio, este advogado não foi denunciado e tão somente foi arrolado como testemunha de acusação. 
$\mathrm{Na}$ época das investigações para a abertura de inquérito, trabalhei na $2^{\mathrm{a}}$ Vara da Comarca de Aquiraz/CE e prestei depoimento ainda na fase de inquérito, bem como pude vivenciar o clima que pairava dos demais funcionários e advogados no decorrer depoimentos.

$\mathrm{O}$ inquérito se originou devido à denúncia de uma ex-funcionária da comarca de Aquiraz e partir disso vieram gravações, bem como escutas telefônicas que estão acostadas aos autos.

Com a delação de um dos investigados, surgiram indícios de outras provas documentais, novos depoimentos e colaborou para trama da denúncia ofertada pelo Ministério Público.

O fato é que, me chamou atenção foi a forma que Ministério Público atuava nas investigações e conduziam os depoimentos, de forma bem incisiva e de certa forma acusatória e assim, levantou-se questionamentos acerca da voluntariedade e espontaneidade que perfazem a delação premiada, bem como questionamentos acerca do valor probatória da delação para o surgimento de ação penal.

Com base nesses questionamentos, surgiram outros e com o intuito de conhecer um pouco mais sobre o instituto da delação premiada surgiu o presente trabalho monográfico, abordando os principais aspectos.

\section{Conclusão}

Destacou-se na presente trabalho monográfico que delação premiada e colaboração à justiça não são expressões sinônimas, pois o colaborador que confessa seu envolvimento em prática em um delito e aponta outros envolvidos deste mesmo crime, configura delação premiada.

Viu-se, quanto à natureza jurídica, que a doutrina dominante sustenta a ausência de semelhança com qualquer prova nominada. Concluindo por tratar-se de espécie de prova, apesar de não se localizar enumerada entre aquelas previstas no Código de Processo Penal brasileiro, nos artigos 158 a 250 , sendo denominada de prova inominada.

A Delação Premiada é um instituto empregado para se aprimorar a satisfação dos anseios populares que clamam pela pacificação social e pela diminuição da criminalidade e punição dos infratores.

Muitos doutrinadores intitulam esse instituto eficaz, ao passo que fornece elementos benéficos a um acusado para que confesse e delate seus comparsas, de modo que estes possam também ser julgados pelos crimes praticados, muito embora tenha como óbice a falta de sistematização e harmonia dos dispositivos legais.

A presença da Delação Premiada no transcurso da história de humanidade é inquestionável, sendo um elemento que se mostra presente desde tempos imemoriais e que visa, sobretudo, contribuir para que a Justiça se instaure de forma mais ampla. Todavia, há uma vasta gama de críticas a este 
instituto, sobretudo na execução desta 'Justiça' a preço de elementos que a lei, a sociedade e a própria definição de Direito e Justiça têm como absolutos.

Há, no caso da Delação Premiada, uma recompensa dada pelo Estado ao corréu que confessa a prática criminosa e incrimina terceiros. Todavia, embora a confissão sirva como elemento responsável por fundamentar a decisão jurídica, sendo um apontador de certeza e justiça, a incriminação, por sua vez, assemelha-se - se é que não configura de fato - uma traição, o que é objeto de asco no meio social, não sendo plausível que seja recompensada. Incidem, ainda, elementos desprovidos de uma harmonia perfeita com os ditames constitucionais, da ampla defesa e do contraditório, que são elementos essenciais para a isonomia processual e a equanimidade na lide jurídica e, embora possa ser compreensível tal conduta ante a premissa de se proteger o delator, poder-se-ia se valer de outros meios para assegurar esta proteção, como, v.g., a alteração da identidade civil do delator.

Desta forma, embora seja um instituto responsável por diversas colaborações para a punição da criminalidade, a Delação Premiada é um instituto controverso, cuja incidência, tal como atualmente se apresenta, é eivada de diversos pontos desabonadores, sobretudo sob o prisma da moral e da ética, que são os ditames da interação e conduta social, os quais são os objetos de aferição do Estado, tendo as leis como causa primeira.

Na sociedade atual o ideal seria que o Estado pudesse apurar delitos de maneira suficiente ao ponto de punir os culpados sem necessitar da ajuda dos criminosos. Mas como isso não acontece, o legislador através do direito comparado, adotou a delação premiada no ordenamento jurídico com a finalidade de banir organizações criminosas e identificar seus membros. Dessa forma, foram estabelecidas vantagens aos colaboradores que delatarem seus companheiros, tais como a isenção e redução de pena, sendo este prêmio uma medida de política criminal, de um lado interessando ao Estado que o criminoso interrompa a sua ação delituosa e por outro permitindo a descoberta de crimes de difícil resolução.

Porém, o direito para ser duradouro, deve assentar-se em uma base ética firme, sendo que ele existe em função de valores que atualmente estão expostos na Constituição Federal. Em alguns casos, é admissível o prevalecimento de alguns direitos sobre outros, mas o que não se pode permitir é a transformação do direito em um instrumento de valores contraditórios. Além disso, a delação premiada estimula o aumento de erros judiciários, pois não há que se negar a existência de declarações falsas e vingativas, somente com intuito de receber o prêmio prometido pela lei.

Portanto, leis infraconstitucionais estão indo contra os princípios consagrados na Constituição Federal, ao passo que a delação premiada fere princípio da proporcionalidade da pena, pois traça a possibilidade de diminuição da pena de um delator, que contribuiu para a prática do mesmo crime como o próprio delatado. Dessa maneira, o Estado deve ser responsável pelo combate à criminalidade sem beneficiar os réus colaboradores através da delação premiada, ou se assim preferir, deve regulamentar o instituto para que não ocorram mais abusos e violações de direitos. 
$\mathrm{O}$ ato de delatar alguém às autoridades expõe o delator e a sua família à provável represália dos outros coautores ou partícipes do crime, pois a traição nesses casos é considerada um dos piores comportamentos num ambiente carcerário. Diante disso, muitos condenados preferem cumprir suas penas em maior tempo, pois se sentem mais protegidos do que se estivessem cumprindo em menor período, ficando à mercê de seus antigos comparsas. Visualizando o problema da delação premiada sob esta perspectiva, não restam dúvidas que as garantias processuais penais dos delatores são violadas.

Por fim foi exposto um estudo de caso para melhor compreensão da aplicação da delação premiada no curso do processo criminal, ressaltando a forma de investigação e direcionamento dos interrogatórios do Ministério Público, fazendo uma análise com os princípios constitucionais atingidos e os requisitos para a concessão desse instituto.

\section{Referências}

AKAOWI, Fernando Reverendo Vidal. Apontamentos sobre a delação. Revista dos Tribunais, São Paulo, 1994, v. 707.

ALVES, Fábio Wellington Ataíde. O retorno dos prêmios pela cabeça? Um estudo sobre a possibilidade de reperguntas no interrogatório do co-réu delator, com enfoque a partir do direito de mentir e do novo ordenamento da delação premial. Revista dos Tribunais, São Paulo, 2003, v. 809.

ARANHA, Adalberto José Q. T. de Camargo. Da prova no processo penal. 5. ed. São Paulo: Saraiva, 1999.

AZEVEDO, David Teixeira de. A colaboração premiada num direito ético. Boletim IBCCrim, São Paulo, n. 83, out. 1999.

BARREIROS, José Antonio. Processo penal. Coimbra: Livraria Almedina, 1981.

BITTAR, Walter Barbosa. Delação Premiada: direito estrangeiro, doutrina e jurisprudência. 2. ed. Rio de Janeiro: Lumen Juris, 2011.

BOSCHI, José Antônio Paganella. Das penas e seus critérios de aplicação. Porto Alegre: Livraria do Advogado, 2000.

BRASIL Lei no 9.613, de 3 de março de 1998. Dispõe sobre os crimes de "lavagem" ou ocultação de bens, direitos e valores; a prevenção da utilização do sistema financeiro para os ilícitos previstos nesta Lei; cria o Conselho de Controle de Atividades Financeiras - COAF, e dá outras providências. DOU de 4.3.1998.

BRASIL. Lei $\mathrm{n}^{\text {o }}$ 9807, de 13 de julho de 1999. Estabelece normas para a organização e a manutenção de programas especiais de proteção a vítimas e a testemunhas ameaçadas, institui o Programa Federal de Assistência a Vítimas e a Testemunhas Ameaçadas e dispõe sobre a proteção de acusados ou condenados que tenham voluntariamente prestado efetiva colaboração à investigação policial e ao processo criminal. DOU de 13.07.1998. 
BRASIL. Lei $\mathrm{n}^{\circ} 7492$, de 16 de junho de 1986. Define os crimes contra o sistema financeiro nacional, e dá outras providências. DOU de 03.06.1986.

BRASIL. Lei $\mathrm{n}^{\circ}$ 8137, de 27 de dezembro de 1990. Define crimes contra a ordem tributária, econômica e contra as relações de consumo, e dá outras providências. DOU de 27.12.1990.

BRASIL. Lei $\mathrm{n}^{\circ}$ 8027, de 25 de julho de 1990. Dispõe sobre os crimes hediondos, nos termos do art. $5^{\circ}$, inciso XLIII, da Constituição Federal, e determina outras providências. DOU de 25.07.1990.

BRASIL. Lei $\mathrm{n}^{\circ}$ 9080, de 19 de julho de 1995. Acrescenta dispositivos às Leis $\mathrm{n}^{\circ} \mathrm{s} 7.492$, de 16 de junho de 1986, e 8.137, de 27 de dezembro de 1990. DOU de 19.07.1995.

BRASIL. Lei $\mathrm{n}^{\circ}$ 11.343, de 23 de agosto de 2006. Institui o Sistema Nacional de Políticas Públicas sobre Drogas - Sisnad; prescreve medidas para prevenção do uso indevido, atenção e reinserção social de usuários e dependentes de drogas; estabelece normas para repressão à produção não autorizada e ao tráfico ilícito de drogas; define crimes e dá outras providências. DOU e 23.08.2006.

BRASIL. Lei $\mathrm{n}^{\circ} 12.850$, de 2 de agosto de 2013. Define organização criminosa e dispõe sobre a investigação criminal, os meios de obtenção da prova, infrações penais correlatas e o procedimento criminal; altera o Decreto-Lei $\mathrm{n}^{\mathrm{O}} 2.848$, de 7 de dezembro de 1940 (Código Penal); revoga a Lei no 9.034, de 3 de maio de 1995; e dá outras providências. DOU de 02.08.2013.

BRASIL. Lei 10.792 , de $1^{\circ}$ de dezembro de 2003. Define organização criminosa e dispõe sobre a investigação criminal, os meios de obtenção da prova, infrações penais correlatas e o procedimento criminal; altera o Decreto-Lei no 2.848 , de 7 de dezembro de 1940 (Código Penal); revoga a Lei $\mathrm{n}^{\mathrm{o}}$ 9.034, de 3 de maio de 1995; e dá outras providências. DOU de 01.12.03.

BRASIL. Código Penal Brasileiro. In: Vade mecum. 18. ed. atual. e amp. São Paulo: Saraiva, 2014.

BRASIL. Legislação Complementar. In: Vade mecum. 18. ed. atual. e amp. São Paulo: Saraiva, 2014.

BRASIL. Constituição (1988). Constituição da República Federativa do Brasil. Brasília, DF: Senado Federal, 1988.

Superior Tribunal de Justiça. Penal. Habeas Corpus. HC n 35.198-SP Segunda Região, Relator: Ministro Gilson Dipp, Processo: 200302010155542. Órgão julgador: Quinta Turma. Data da decisão Dje: 28/09/2004.

Superior Tribunal de Justiça. Penal. Habeas Corpus. HC no 40.633-SP Segunda Região, Relator: Ministro Arnaldo Esteves Lima, Processo 2004/0182951-8. Órgão julgador: Quinta Turma. Data da decisão Dje: 01/09/2005.

CAPEZ, Fernando. Curso de processo penal. 9. ed. ver. e atual. São Paulo: Saraiva, 2003.

CERVINI, Raúl; GOMES, Luiz Flávio. Crime organizado: enfoque criminológico, jurídico e politico-criminal. São Paulo: Revista dos Tribunais, 1995.

CUNHA, Rogério Sanchez; TAQUES, Pedro; GOMES, Luiz Flávio. Limites constitucionais da investigação. São Paulo: Revista dos Tribunais, 2009.

FEITOZA, Denilson. Direito processual penal. Rio de Janeiro: Impetus, 2009. 
FERREIRA, Aurélio Buarque de Holanda. Novo Aurélio Século XXI: Dicionário da Língua Portuguesa. 3 ed. Rio de Janeiro: Nova Fronteira, 1999.

FRANCO, Alberto Silva. Crimes Hediondos: Anotações sistemáticas à Lei 8072/90. 4 ed. rev. atual.e ampl. São Paulo: Revista dos Tribunais, 2000.

GUIDI, José Alexandre Marson. Delação Premiada: no combate ao crime organizado. Franca/SP: Lemos e Cruz, 2006.

GUIDI, José Alexandre Marson. Delação Premiada no combate ao crime organizado. Franca-SP: Lemos \& Cruz, 2006.

GUIDI, José Alexandre Marson. Delação premiada no combate ao crime organizado. Franca-Sp: Lemos de Oliveira Editora e Distribuidora Ltda-ME, 2006.

GOMES, Luiz Flávio. Corrupção Política e Delação Premiada. Revista Síntese de Direito Penal e Processual Penal, ano VI, n. 34, Porto Alegre: out.-nov. 2005.

GOMES, Luiz Flávio e CERVINI, Raúl. Crime organizado. 2. ed. São Paulo: RT, 1997.

GRECCO, Rogério. Código penal comentado. 2. ed. Rio de Janeiro: Impetus, 2009.

IHERING, Rudolf Von. A luta pelo direito. 23. ed. rev. Rio de Janeiro: Forense, 2004.

JESUS, Damásio E. de. Estágio atual da "delação premiada" no Direito Penal brasileiro. Jus Navigandi, Teresina, a. 10, n. 854, 4 nov. 2005. Disponível em: <http://jus2.uol.com.br/doutrina/texto.asp?id=7551>. Acesso em: 15 abr. 2015.

JESUS, Damásio de. Delação premiada. In: Revista Justilex. Brasília, ano IV, n. 50, fevereiro de 2006.

LEAL, João José. A lei $9.807 / 99$ e a figura do acusado-colaborador ou prêmio à delação. RT/Fascículos Penais, s.1, ano 89, v. 782, p. 443-458, dez. 2000.

MAIA, Rodolfo Tigre. Dos crimes contra o sistema financeiro nacional: anotações à lei federal n. 7.492/86. São Paulo: Malheiros, 1999.

MAlATESTA, Nicola Framarino Dei. A Lógica das Provas em Matéria Criminal. [s.l.]: Conan, 1995. v. 2.

MAIEROVITCH, Walter Fanganiello. Apontamento sobre a política criminal e a plea bargaining. Revista dos Tribunais. São Paulo: RT, n. 678, 1992.

MENDRONI, Marcelo Batlouni. Crime organizado: aspectos gerais e mecanismos legais. São Paulo: Editora Juarez de Oliveira, 2002.

MONTE, Vanise Röhrig. A necessária interpretação do instituto da delação premiada, previsto na lei 9.807/99, à luz dos princípios constitucionais. Revista da Ajuris. Porto Alegre, vol. 82, 2001.

MOREIRA, Rômulo de Andrade. Delação no Direito Brasileiro. Revista Síntese de Direito Penal e Direito Processual Penal, Porto Alegre, n. 19, 2003.

NUCCI, Guilherme de Souza. Código penal comentado. 2. ed. São Paulo: Revista dos Tribunais, 2002.

104 Id en lime Revista de Psicologia. Ano 9, No. 28. Novembro/2015 - ISSN 1981-1179. Edição eletrônica em http://idonline.emnuvens.com.br/id 
NUCCI, Guilherme de Souza. Leis penais e processuais penais comentadas. 2. ed. rev., atual. e ampl. São Paulo: RT, 2007.

QUEIJO, Maria Elizabeth. O direito de não produzir prova contra si mesmo: o princípio nemo tenetur se detegere e suas decorrências no processo penal. São Paulo: Saraiva, 2003.

PACHECO, Vilmar; THUMS, Gilberto. Nova lei de drogas: crimes, investigação e processo. Porto Alegre: Verbo Jurídico, 2007.

PACHI, Laís Helena Domingues de Castro. Delação Penal Premial. São Paulo: PUC, 1992. Monografia (Mestrado em Direito Penal), Faculdade de Direito, Pontifícia Universidade Católica de São Paulo, 1992.

PEREIRA, Alexandre Demetrius. Lei de proteção: às testemunhas ou aos criminosos? Jus Navigandi, Teresina, a. 3, n. 34, ago. 1999. Disponível em: 〈http://jus2.uol.com.br/doutrina/texto.asp?id=1004〉. Acesso em: 11 fev. 2015.

RAMOS, João Gualberto Garcez. Curso de processo penal norte-americano. São Paulo: RT, 2006.

TOURINHO FILHO, Fernando da Costa. Processo Penal. 27. ed. rev. e atual. São Paulo: Saraiva, vol. 3,2005 .

\section{Como citar este artigo (Formato ABNT):}

MOTA, T.A.; LEITE,C.P.B. Delação Premiada no Direito Brasileiro. Id on Line Revista de Psicologia, Novembro de 2015, vol.9, n.28. p. 78-105. ISSN 1981-1189.

Recebido: 10/08/2015

Aceito: 18/09/2015 